\title{
Angles
}

New Perspectives on the Anglophone World

$10 \mid 2020$

Creating the Enemy

\section{Cannibals, Monsters and Weasels: Creating a French Enemy in the United States during the 1790s Quasi-War and the 2003 Iraq War Diplomatic Crisis}

Hervé-Thomas Campangne

\section{(2) OpenEdition}

\section{Journals}

Electronic version

URL: http://journals.openedition.org/angles/408

DOI: 10.4000 /angles.408

ISSN: 2274-2042

\section{Publisher}

Société des Anglicistes de l'Enseignement Supérieur

Electronic reference

Hervé-Thomas Campangne, "Cannibals, Monsters and Weasels: Creating a French Enemy in the United States during the 1790s Quasi-War and the 2003 Iraq War Diplomatic Crisis », Angles [Online], 10 | 2020, Online since 01 April 2020, connection on 28 July 2020. URL : http:// journals.openedition.org/angles/408; DOI : https://doi.org/10.4000/angles.408

This text was automatically generated on 28 July 2020 .

Angles. New Perspectives on the Anglophone World is licensed under a Creative Commons AttributionNonCommercial-ShareAlike 4.0 International License. 


\title{
Cannibals, Monsters and Weasels: Creating a French Enemy in the United States during the 1790s Quasi-War and the 2003 Iraq War Diplomatic Crisis
}

\author{
Hervé-Thomas Campangne
}

Countless U.S. presidents and leaders, including Ronald Reagan, Barack Obama and Donald Trump, have reminded Americans that France is their country's "oldest ally" (Riché 2013; Seelow 2013; Obama 2015; Serhan 2017). Likewise, many a French official has underscored the unwavering and "natural" quality of the commitment between France and the United States (De Gaulle 1965; Mitterrand 1984; Macron 2018). Yet political scientists and historians often point to the cyclical nature of French-American relations (Duroselle 1978; Bozo and Parmentier 2007: 545). They have shown that since the 1778 Treaty of Amity and Commerce that sealed the alliance between the American insurgents and the monarchy of Louis XVI, periods of collaboration and alignment have alternated with times of tension and division. High moments include the 1781 Siege of Yorktown, Colonel Stanton's "Lafayette, we are here" speech as the first American Expeditionary Force arrived in France in 1917, the D-Day landings in Normandy in 1944, and more recently, the close cooperation between the two countries' intelligence agencies in their efforts to counter terrorism. Times of conflict comprise president Andrew Jackson's and king Louis Philippe's disagreement over spoliation claims dating back to the Napoleonic wars, the aftermath of the 1956 Suez crisis, General De Gaulle's 1966 decision to withdraw France from NATO's integrated military command, and France's refusal to allow U.S. aircraft to fly over its territory during the American raid against Muammar Qaddafi's Libya in 1986.

2 Among the discords between the two countries, two diplomatic crises especially stand out. The first one induced the 1790s Quasi-War. The French directorate perceived the 
1795 Jay Treaty, which restored economic relations between the United States and Great Britain, as a betrayal on the part of its American allies, and consequently allowed for seizure of American merchant ships. In July 1797, newly elected president John Adams sent a mission to France to avoid an all-out war. Upon arriving in Paris, the American diplomats Gerry, Pinckney and Marshall were met by intermediates who demanded a substantial bribe and a low-interest American loan before they could meet foreign minister Talleyrand. The American envoys refused, and after their dispatches reached the United States, president Adams disclosed the correspondence to Congress, replacing the names of the French agents with the letters $\mathrm{X}, \mathrm{Y}$, and $\mathrm{Z}$. "As the humiliation suffered by the mission in Paris became clear", historian Alexander DeConde writes, "many Americans became outspokenly anti French" (DeConde 1966: 75). Protests erupted in Philadelphia demanding war with France, the Federalistcontrolled Congress passed legislation to fund a naval force, as well as the Alien and Sedition Acts of 1798, which provided a form of response to the perceived French threat. The undeclared war continued until the convention of 1800 and the Treaty of Mortefontaine, which reestablished more friendly relations between the two countries. During the hostilities, France had seized over 2000 American ships. ${ }^{1}$

3 Two hundred years after the Quasi-War, another major diplomatic crisis created deep divisions between the two nations following France's refusal to support the American military intervention in Iraq in 2003. After foreign minister Villepin's January 20, 2003 speech at the United Nations Security Council, in which he reiterated the French position that arms inspections, rather than war, could provide an effective response to the imperative of disarming Iraq, United States government officials accused France of obstructing American efforts to oust dictator Saddam Hussein. ${ }^{2}$ The anger of those who intended to "punish France" and make it "pay" for its opposition (Bozo 2016: 276) was soon relayed by a media campaign that sparked an intense wave of Francophobia and contempt for everything French in the United States. Columnist Charles Krauthammer contended in The Washington Post that "France has gone far beyond mere obstruction, it is engaged in sabotage", and his New York Times colleague Thomas Friedman went as far as writing of "our war with France" (Friedman 2003). Other editorialists wrote of the best way "to teach France a lesson" (Mitchell 2003). The French embassy received hundreds of hateful emails and telephone calls (Skoloff 2003), American families refused to host French students because it allegedly represented "too great a risk of unpleasantness in public places" (Willsher \& Laurence 2003), stores bearing French names were vandalized, and in one instance, an ex-marine murdered a Florida bartender who had the bad idea of criticizing the war in Iraq and speaking French with his girlfriend on the telephone. The murder was later deemed racist by the court (Bozo 2016: 274).

4 In the late 1700 s as well as the early 2000 s, the French were widely depicted as America's antagonist. The aim of this article is to provide an understanding of the process through which the image of France was transformed, in both instances, from that of ally and friend into that of a threatening other. Particular attention will be paid to the creation and use of cultural stereotypes in official statements, as well as in the media campaigns that marked both diplomatic crises. My working hypothesis is that although the enemy image of France underwent significant changes between 1797 and 2003, a number of cultural stereotypes that were created during the Quasi-War were reactivated during the 2003 diplomatic rift. 
5 This article will also examine the domestic political divisions that provided the context, in the United States in 1797 and 2003, for the creation of enemy images of France that illustrate the classic paradigm that "inventing an enemy begins, paradoxically, with the invention of the self" (Vuorinen 2012: 1). In both instances, the French antagonist was a mirror and a scapegoat that provides as much information on American identity and U.S. political debates as it does about American views on France and the French.

Since my theoretical approach is that of cultural history, I have relied on a wide variety of sources. Studies and articles by historians and political scientists have provided analyses of the diplomatic and political foundations of the Quasi-War and Iraq crisis. For the study of images of France and the French, I have relied on newspapers and magazine articles contemporary of both crises, as well as on various forms of satirical media. Works by cultural historians, as well as by specialists of International Relations, have provided a theoretical framework through which to understand the creation and functioning of cultural stereotypes and enemy images.

\section{When Friends Become Enemies}

7 In his seminal book How Enemies Become Friends: The Sources of Stable Peace, Charles A. Kupchan describes the process through which hostile nations replace competition and aggression with friendship and cooperation in order to achieve reconciliation. Among the key ingredients needed for rapprochement and peace, Kupchan lists "the generation of new narratives and identities":

Through elite statements, popular culture (media, literature, theatre), and items laden with political symbolism such as charters, flags, and anthems, the states in question embrace a new domestic discourse that alters the identity they possess of the other. The distinctions between self and other erode, giving way to communal identities and a shared sense of solidarity, completing the onset of stable peace (Kupchan 2010: 6)

Relations between the United States and France in 1797-98 and 2003-2004 followed a path that was the exact opposite of the course described above. In both instances, official statements opened the way to media campaigns that resulted in the creation of an enemy image of France that was accepted by a significant portion of the American public. $^{3}$

9 During both crises, the "elite statements" that signaled that France had become an antagonist in the eyes of American officials came from the highest levels of government: in 1798, President Adams repeatedly issued calls to arms against the French in front of town assemblies, societies and militia companies (DeConde 1966: 81), while Representatives in Congress advocated "open and deadly war with France" (Bowman 1974: 331). In 2003, Secretary of Defense Donald Rumsfeld's reproach that "France has been a problem" (Rumsfeld 2003), Secretary of State Condoleezza Rice's willingness to "punish France", and Colin Powell's assertion that France would be made to suffer for its opposition to the war (Knowlton 2003a) prompted editorialist Thomas Friedman to write in The New York Times: "It's time we Americans came to terms with something: France is not just our annoying ally. It is not just our jealous rival. France is becoming our enemy" (Friedman 2003). These lines sum up the spirit of a media campaign whose effects paralleled the damaging work carried out by the press in the context of the 1790s Quasi-War. 
10 In 2003 as in 1798, the media accomplished what the polished language of international diplomacy could not: it spread deprecatory images of France and the French in order to rouse public opinion against a nation that came to incarnate everything un-patriotic and un-American. In both cases, the media campaigns were carefully orchestrated. In 1797-8, three quarters of the press supported the administration's stance against France (DeConde 1966: 79). Federalist newspapers such as The Boston Gazette and New York Commercial Advertiser became fora for all those who sought to spread rumors of an impending invasion of the United States by French troops, calling for military action against France. Alexander Hamilton himself took to pen under the pseudonym "Titus Manlius" to publish a series of articles titled "The stand". "Like the prophet of Mecca", he wrote in one of these columns, "the tyrants of France press forward with the alcoran of their faith in one hand, and the sword in the other" (Hamilton 1798). The association between Frenchmen and Muslims, a topos that would be widely used in 2003 as well, can be seen as the justification of a crusade-like enterprise.

11 In 2003, leaks from alleged "anonymous administration officials" (Ireland 2003) provided the source of articles accusing France of selling military equipment to Saddam Hussein's Iraq. As noted by political scientist Justin Vaïsse, the breadth and depth of the disinformation campaign against France was striking: anti-French articles did not only appear in controversial papers such as The Washington Times and New York Post, ${ }^{4}$ but also in prestigious and widely read outlets such as The New York Times, The Washington Post, and Newsweek (Vaïsse 2003b).

\section{From Monstrous France to France the Weasel}

12 At the time of the Quasi-War as well as during the 2003 Iraq crisis, the media campaigns against France offered a potent illustration of the classic paradigm of dehumanization and demonization described by Jerome Frank and Andrei Melville in their study on "The image of the enemy and the process of change" (1988). Members of the allegedly hostile group were depicted "as bestial and subhuman on the one hand, and diabolically clever on the other" (Frank \& Melville 1988: 201).

One image especially stands out in the flow of caricatures and demeaning representations of the Gallic nation characteristic of the late 1790s: France and the French were described as monstrous, bloodthirsty creatures that needed to be suppressed by sheer reason of their inhumanity. An article in the August 27, 1798 Boston Gazette resorted to atrocity propaganda, comparing the French Jacobins to an impressive list of tyrants, barbaric invaders, and threatening others: "Nero- Caligula the Goths and Vandals - Nay! our wild Indians, compared with the democratic rulers of the French, have been but infants in the practice of Treason, Murder and Rapine". French nationals whom the author of the article accuses of having murdered the crew of the ship Hunter are then likened to cannibals, in reference to an anti-Jacobin pamphlet titled The Cannibal's progress, that described the atrocities committed during the invasion of Swabia by the French Republican army. ${ }^{5}$ The object of his article, the author told his readers, was "that by impressing upon your minds the perfidy, cruelty and wickedness of the enemy you now have to contend with, you may become alarmed, more animated, firm, and united".

If the French were savages and cannibals, their nation could be depicted as a "Harlequin creature, now vapouring on the national stage with a head of brass and 
triple ribbons, with a heart, the ark of impiety, with finger dropping blood", recognizable by "her gypsy gibberish, her monkey gestulation [sic], her habitual perfidy, her impiety to God, or her cruelty to men" (Farmer's Weekly Museum, January 2, 1798). A striking depiction of France as a monster appeared in a political cartoon titled "Cinque tetes or the Paris Monster", satirizing the XYZ affair (Figure 1). It depicts the American envoys responding to a five-headed creature representing the five members of the French Directorate: "Cease bawling, monster! We will not give you six pence". In the background, a group including a black man, who represents freed slaves, is feasting on frogs, under the gaze of an allegory of France represented as a hideous "Lady guillotine", who has just decapitated a citizen. With these images, the struggles of the United States against France were presented as more than a diplomatic and economic conflict: they became the battle of two diverging concepts of the republic, one upholding values of civilization and freedom, while the other chose the vices of barbarism, tyranny and terror.

Figure 1. Cinque tetes or the Paris Monster

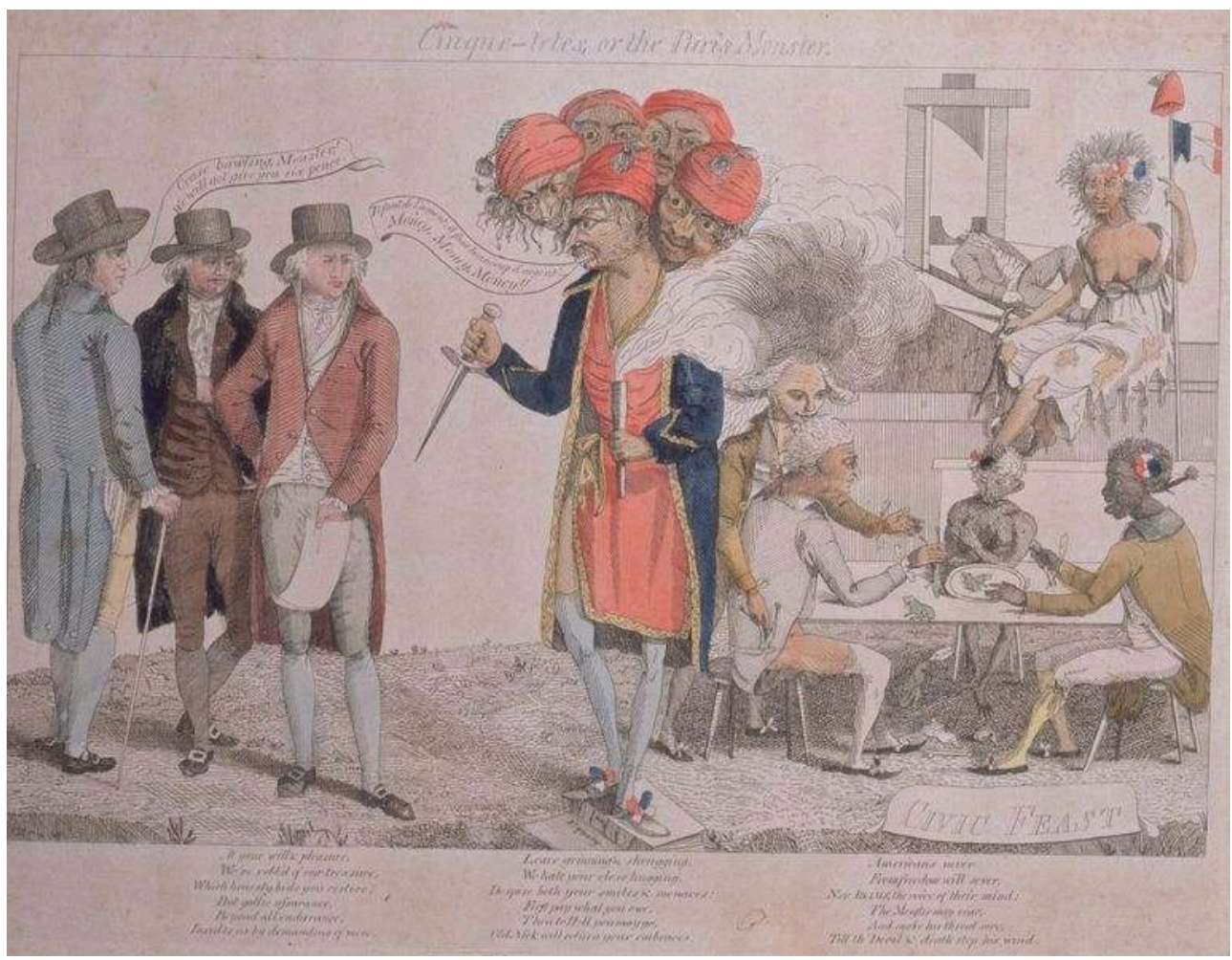

Cartoon satirizing the $\mathrm{XYZ}$ affair. 1797

Significantly, dehumanizing images of France and the French were also disseminated during the 2003 press campaign against a nation that was blamed for organizing worldwide resistance to the United States' efforts in the Middle East. In the Wall Street Journal, Christopher Hitchens described Jacques Chirac as "a positive monster of conceit [...] the abject procurer for Saddam [...] the rat that tried to roar" (Young \& Henley, 2003). An enemy image of France quite different from, but no less striking than that of the cannibalistic monster of the Quasi-War began to spread in the media: France was now a malevolent rodent, a "weasel" that undermined and threatened American efforts. If the Quasi-war of the 1790s came close to tragedy, the 2003 diplomatic conflict 
with France was a sinister farce. The February 14, 2003 cover of The New York Post displayed a doctored picture of a United Nations meeting in which the French and German diplomats were represented as monstrous half-human, half-weasel creatures (Figure 2). Although the Gallic nation certainly no longer posed a direct military threat as it had in the late 1790s, it deserved, in the words of columnist Ralph Peters, "to be skinned alive" (Peters 2003) because of its perceived betrayal of the United States. Monster or rodent, the French enemy of 1798 and 2003 was stripped of its humanity, in classic war rhetoric fashion: as David Livingstone Smith has shown, comparing people to monsters or animals is a distancing tactic, a justification of bellicose intentions, and "a way of reassuring ourselves that they are so different from us" (Smith 2011: 136). In 1798 and 2003, France became a primary target of the racist, xenophobic and demeaning stereotypes that flourish in times of geopolitical conflict.

Figure 2. Cover of The New York Post, February 14, 2003

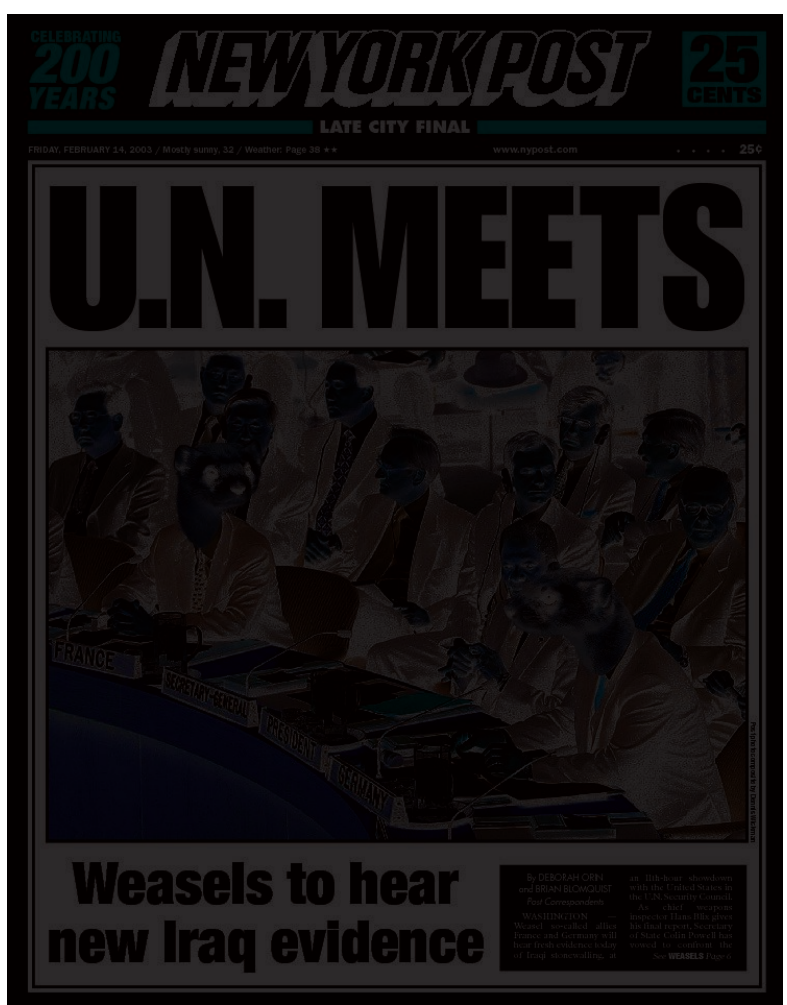

Source: https://nypost.com/cover/post-covers-on-february-14th-2003

If the anti-French campaigns of 2003 and 1797-98 share many features, the availability of new forms of media gave twenty-first century proponents of "French bashing" an advantage over their distant ancestors. Beyond the traditional newspapers and magazines, Francophobes could reach wide audiences through the radio, television and the internet. Late-night show hosts and comedians reveled in telling anti-French jokes. Topoi inherited from the complaints of American soldiers in World War II were often used for the occasion ${ }^{6}$ : references to the French capitulation in 1940, to bad hygiene and loose sexual mores abounded. Stereotyping characteristic of the "system of Francophobia" analyzed by Jean-Philippe Mathy (2003) could be witnessed on most television networks: “I don't know why people are surprised that France won't help us get Saddam out of Iraq. After all, France wouldn't help us get the Germans out of 
France!", Jay Leno told the audience of NBC's The Tonight Show, a program that reached an average 5.9 million Americans nightly. ${ }^{7}$ David Letterman, his competitor on CBS' Late Show quipped that "The last time the French asked for 'more proof' it came marching into Paris under a German flag," while comedian Conan O'Brien turned Saddam Hussein into the caricature of a Frenchman: "You know why the French don't want to bomb Saddam Hussein? Because he hates America, he loves mistresses and wears a beret. He IS French, people" (Lewis 2006). On the internet, anti-French blogs and websites flourished, many of them calling for a boycott of French products, a call that was echoed by commentator Bill O'Reilly on his Fox News channel show, as well as by an advertisement in the March 26, 2003 issue of The New York Times. The impact of the France-U.S. dispute was such that even the market share of French-sounding brands significantly declined, as shown by a study published in the Review of Economics and Statistics (Pandya \& Venkatesan 2016).

17 In 2003-4, attacks on France in the popular media were also relayed by a slew of publications by scholars who sought to rewrite the history of French-American relations. Different segments of the American population, from television viewers to readers of newspapers and buyers of history books, were thus exposed to Francophobe attacks. Mark Molesky (a professor at Seton Hall University) teamed up with National Review journalist John J. Miller to publish Our Oldest Enemy: A History of America's Disastrous Relationship with France. Harlow Giles Unger (a former Distinguished Visiting Fellow in American History at George Washington's Mount Vernon) penned The French War against America. ${ }^{8}$ In both publications, negative filtering provided a devastating narrative of French treachery, backstabbing and dishonesty spanning more than two hundred years. According to Unger, contrary to what most Americans believe, "the French did not support the American Revolution to help create a free and independent new nation, but to try to restore French sovereignty over North America"; De Gaulle waged a propaganda war against the United States "to ensure his own accession to the presidency after world war II" (Unger 2005). Molesky and Miller would have their readers believe that "America's first authentic sense of self was born not in a revolt against Britain, but in a struggle with France". The authors of Our Oldest Enemy also claim that the GIs "literally had to fight their way through the French to get to the Nazis" (Molesky \& Miller 2004), that the French, with the debacle at Dien Bien Phu, were solely responsible for America's quagmire in Vietnam, and that all French leaders have shared the common goal of maneuvering against the United States across the globe. Such accusations prompted political scientist Stanley Hoffman to write in Foreign Affairs:

That a book as shoddy and biased as this one should be published by a reputable press is eminently regrettable [...] instead of providing an honest account of the facts and attempting to discern reasons behind them, the authors offer only vituperation and contempt (Hoffman 2004: 153)

Unger and Molesky's books certainly provided enemy images of France that acted "like distorting lenses that magnify confirming information and filter out incompatible information" (Frank \& Melville 1988: 201) in order to rewrite the history of France-U.S. relations. In both publications, the episode of the Quasi-War figured prominently: the authors contended that this prolonged season of hostilities was sufficient proof that the French had been the treacherous enemies of the United States as far back as the $18^{\text {th }}$ century. 


\section{Conspiracy theories and disinformation}

19 In 1798 and 2003, writing a new narrative of French-American relations also entailed the "Items laden with political symbolism such as charters, flags, and anthems" described by Kupchan (2010: 6) as essential to the process of rapprochement between hostile nations. During the Quasi-War and Iraq crisis, they played an opposite role as Francophobes made them a target in the process of degrading a nation that had previously enjoyed the status of ally and friend. At the time of the Quasi-War, many Americans replaced the tricolor cockade that they had worn as a tribute to the sister republic of France with the black cockade of the Federalists (DeConde 1966: 83). In a letter to her sister, First Lady Abigail Adams noted how French songs became an object of public scorn in Philadelphia theatres:

French Tunes have for a long time usurped an uncontrould sway. since the Change in the publick opinion respecting France, the people began to lose the relish for them, and What had been harmony, now becomes discord. accordingly their had been for several Evenings at the Theatre something like disorder, one party crying out for The Presidents march, and yankee Doodle, whilst Ci era, was vociferated from the other it was hisst off repeatedly. the managers were blamed. (Adams 1798)

In 2003 also, traditional French symbols became objects of scorn. Hotel chain Sofitel's decision to remove the French flags in front of all of its hotels in the United States as a precautionary measure is indicative of the depth of the anti-French sentiment. "Sofitel surrenders, lowers French flag" journalist Rob Kaiser ironically wrote in the Chicago Tribune as the hotel chain's directors decided to replace the tricolor with flags of American states and cities. One of the best-remembered expressions of "Frenchbashing" in the wake of the Iraq war disagreement was the decision to change the name of "French fries" to "Freedom fries" on the cafeteria menus of the three House office buildings, and subsequent renaming of "French toast" into "liberty toast" on the menu aboard presidential plane Air Force One (Loughlin 2003). Although there is nothing intrinsically French in fries nor in toast cooked with egg batter, the American "war" with France was clearly a war of words and symbols: just as "sauerkraut" had been renamed "liberty cabbage" by patriotic Americans after the entry of the United States into World War I, "liberty fries" were meant to show that the French were now on the side of tyranny and evil. In both cases, liberty was the concept of choice in the U.S. to demean the other and praise the self.

Another parallel unites the two diplomatic crises. As French symbols were deprecated and as the media campaigns raged, conspiracy theories began to spread. In April 1798, Robert Goodloe Harper, an ex-Charleston Jacobin turned ardent Federalist, rose before Congress to warn of an impending invasion by five thousand "black troops" sailing from Saint Domingue. Those black Frenchmen would turn slaves against their masters, he warned, and create an alliance that would soon "destroy the country" (Papenfuse 1997: 29). In the following months, eminent ministers gave sermons in which they alerted their congregations about the evil plans of the illuminati, a secret society whose agents were hiding amongst Americans, preparing a vast conspiracy and takeover of the United States (Den Hartog 2015: 45-69). Boston minister and Yale president Timothy Dwight admonished on July 4, 1798,

Is it that our churches may become temples of reason, our Sabbath a decade, and our psalms of praise Marseillois hymns? Is it, that we may change our holy worship into a dance of Jacobin phrenzy, and that we may behold a strumpet personating a 
goddess on the altars of Jehovah? Shall our sons become the disciples of Voltaire, and the dragoons of Marat or our daughters the concubines of the Illuminati? (Dwight 1798: 20-21) perception of enemy subjects that, as Frank and Melville point out, "seriously weakens inhibitions humans may possess against attacking fellow humans" (Frank \& Melville 1988: 201). An allegation made in The New York Times in September 2002 that France (along with Germany) had sold Iraq high precision switches used to detonate nuclear bombs had a ripple effect through the American media. ${ }^{9}$ Journalists Daniel Mitchell accused the French of "providing Saddam Hussein's brutal regime with valuable technology", and of actively working to sabotage the U.S. campaign against the Iraqi dictator (Mitchell 2003). Theories of French terror conspiracies were echoed by conservative columnist William Safire and Representative Joe Scarborough, and later magnified by Bill Gertz in his Washington Times columns and book Treachery. How America's Friends and Foes are Secretly Arming our Enemies (2004). According to Gertz, U.S. forces had uncovered caches of French-made missiles and other weapons in Baghdad; Gertz also contended that the Iraqis had shot down an American pilot using a French missile, and that the French government had provided passports to secretly help officials from Saddam's regime flee from Iraq (Gertz 2004).

In 2003, as in 1798, the effects of the conspiracy theories were widely felt. During the Quasi-War, the editors of Republican newspapers attempted to rebuke the anti-French allegations and bellicose rhetoric spread by the Federalists. Benjamin Franklin Bache warned readers of his Aurora General Advertiser on August 1, 1798:

In order that "The people" should understand the real point of controversy between France and The US, it is necessary to bring the ultimatum immediately before them [...] Whether it is necessary to commence war on this proposition, and to call them rogues, pirates, and five headed monsters, for this preliminary, is left to the decision, not of agents, contracters, office-seekers, and Georgia-bankrupts, but to YEOMANRY and TRADESMEN, who must finally become private soldiers, and pay their Taxes for the support of the war.

Bache preached to the converted, while his enemies were less receptive. Federalists accused him of being a puppet of the French, and angry mobs attacked his residence (DeConde 1966: 79).

In 2003, responses to French conspiracy theories ranged from embassy spokesperson Nathalie Loiseau qualifying American allegations of French cooperation with Iraq as "untrue [...] and insulting" (Stanley 2003), to Ambassador Jean-David Levitte's formal complaint that France was the victim of a campaign of "repeated disinformation" (Knowlton 2003). Levitte's letter to the White House, State Department and Congress, whose content was made public in lengthy articles in The Washington Post and The New York Times, only prompted denials from the White House and Defense Secretary Donald H. Rumsfeld, who told reporters there was no such campaign. The effects of these French complaints on American opinion are difficult to document, especially since political scientists generally agree that "people tend to be receptive to information that confirms the beliefs they already hold and that individuals are most likely to respond to messages that resonate with their existing predispositions" (Hayes \& Guardino 2010: 64). No matter what the French said, in the Spring of 2003, $40 \%$ of Americans did not consider France to be an ally of the U.S., with $31 \%$ who said that France was "unfriendly", and 9\% who considered France "an enemy" (Saad 2003). Another poll 
showed that $64 \%$ of Americans held a "mostly unfavorable" or "very unfavorable" view of France (Gallup Country ratings 2003).

\section{The enemy within}

As indicative as it was of tense diplomatic relations between the two countries, the fabrication of a French enemy during the Quasi-War and Iraq crisis was also a reflection of internal political divisions in the United States. In the late 1790s, the transformation of France from ally and friend into enemy and foe was used to advance the agenda of a specific political party. At the time, the Federalists sought to "disentangle" the United States from a major colonial empire that had been instrumental in its war for independence from another colonial empire (Great Britain). As Jasper Trautsch points out:

Federalist power brokers envisioned that a military conflict between both countries would discredit the democratic egalitarianism that France symbolized and instead bolster Federalists' conservative definition of American identity (Trautsch 2018: 131).

Since France was one of the superpowers of the time, creating an enemy image of the Gallic nation amounted to affirming America's independence, its identity as a republic distinct from the type of government established by the French revolution, and its future role as what Eliga Gould has called a "treaty-worthy nation" (Gould 2012: 177). In this context, France was seen as both an enemy without and an enemy within: the Federalists warned of a possible French invasion of the United States and called for an open war with France; they also campaigned for the elimination of American Jacobin clubs, and underscored the nefarious influence of French agents on American politics and government. American supporters of France became extremely suspicious in the eyes of the Federalists, as shown by this article in the January 3, 1797 Courier of New Hampshire:

A most important discovery is announced in Philadelphia - the President of the Bank of Pennsylvania (who, we understand, is a democrat or partizan of France) has drawn out of the bank the enormous sum of one hundred and eleven thousand dollars, and appropriated it to the purpose of his private speculations.

Obviously, not all Americans agreed with President Adams and the Federalistcontrolled Congress. If anything, the XYZ affair widened the gap between Francophobe federalists and Francophile Republicans. However, as Matthew Rainbow Hale notes, it also greatly contributed "to the marginalization of the notion of French and American interconnectedness" (Hale 2003: 171). Indeed, it became increasingly difficult for proFrench citizens to affirm, as they had in the early 1790s, that the independence of the United States required close ties with a country that shared the same democratic, fraternal, and cosmopolitan values. For the Federalists, creating an enemy image of France was also a way to promote a uniquely American form of patriotism and identity that profoundly undermined the concept of French-American linkage.

In 2003 also, the French enemy was largely the invention of a political faction. Francophobia was instrumentalized by neo-conservatives in the Bush administration who sought to advance their agenda of "regime change" in the Middle East, and consequently led the United States to invade Iraq. However, their vision of the best course to take was not shared by all Americans in the early stages of the crisis. A CBS News/New York Times poll showed that $63 \%$ of Americans still favored a diplomatic 
solution over military intervention in late January 2003. Large popular demonstrations against the war took place in New York and other American cities, and many influential senators and congressional Representatives voted against the October 2002 motion to authorize the use of United States armed forces against Iraq. Yet the most visible and outspoken opposition to the war came from abroad, and especially from France. As Hayes and Guardino point out:

Much of the discussion in the months leading up to the invasion focused on the effectiveness of UN sanctions, whether Iraq had violated the sanctions, standards of evidence for the existence of weapons of mass destruction, and other technical details involving international law and regulations. Thus, from the perspective of dominant news norms, UN and other foreign officials were not merely components of an amorphous "other side" in the debate. They were instead central to the development of the story [...] (Hayes \& Guardino 2010: 63-4)

As the "story" presented to the American public increasingly centered on opposition to immediate military action in the United Nations council, "Oleaginous" foreign affairs minister Dominique de Villepin became a favorite target of conservatives like George F. Will, who accused him of leading his country into "an exercise for which France has often refined its savoir-faire since 1870 , which is to say retreat - this time into incoherence" (Will 2003). Donald Rumsfeld depicted France as the best representative of the countries of "old Europe", whose outmoded ways and culture paled in comparison with the energy and potential of the post-communist era countries of eastern and central Europe that constituted a "new Europe" ready to align with the United States. "The French remind me a little bit of an aging actress of the 1940s who is still trying to dine out on her looks but doesn't have the face for it", Senator John McCain stated in an interview (Montgomery 2003): if the comment was meant to be humorous, it still added age-coded stereotypes to the "gender-coded stereotypes" that have historically pegged France as feminine and weak in the American psyche (Rosenthal 1999).

During the 2003 Iraq crisis, the words "French" and "France" became code words for anti-American and unpatriotic: being "French" implicitly meant negating the values of liberty, democracy and courage that constituted the core of Americanness as understood by neo-conservatives. Significantly, France's image fell much more sharply among Republicans than Democrats at the start of the Iraq war in 2003. Between February 2002 and March 2003, Republicans' favorability toward France dropped more than 60 points, from $81 \%$ to $20 \%$, versus a 34-point decline among Democrats, from $79 \%$ to $45 \%$ (The Gallup poll, public opinion 2016). To those who no longer considered France to be an ally of the United States and believed that the Gallic nation was "stabbing the U.S. in the back" (Moore 2003), all expressions of French culture and nationality became suspicious. The lingering effects of this political instrumentalization of the anti-French bias were clearly seen during the 2004 presidential election campaign, as George W. Bush's camp repeatedly underscored democratic candidate John Kerry's ties to France. Commerce Secretary Don Evans called Kerry a "fellow of a different political stripe who looks French", and the Republican National Committee issued regular news releases about Kerry's French relatives and his alleged popularity in France (Milbank 2004). The democratic candidate's consequent refusal to speak French publicly during the rest of the campaign (Wilgoren 2007) attests to the political weight accusations of "Frenchness" still carried in 2004. 


\section{Conclusion: Why France?}

was born at the time of the Quasi-War of the late 1790s. It was then that the association of France with terror and tyranny crystallized, an image that the Federalists turned into a political weapon as they struggled to impose their vision of American identity and sought to affirm U.S. independence on the geopolitical chessboard. This representation of France was reactivated during the 2003 crisis, as the French were depicted as siding with despot Saddam Hussein, and implicitly with Islamist terrorists. Hamilton's 1798 association between a threatening "prophet of Mecca" and the "tyrants of France" found a new incarnation in the rhetoric of those who accused the French of cooperating with one of the leading members of the "axis of evil" in 2003. Other preexisting stereotypes of the French as unreliable, cowardly, difficult, treacherous and effeminate came into play. These stereotypes can be traced as far back as the Hundred Years War (1337-1453). As Rosenthal notes, British colonists in America "absorbed, adapted, and perpetuated the jaundiced views of the mother country" on all things French (Rosenthal 1999: 906). In the 1830s, when the United States attempted to force France to honor spoliation claims for American shipping losses suffered during the Napoleonic Wars, Louis Philippe and his ministers were described as frivolous "canting, hypocritical, smoothfaced" villains (New Hampshire Gazette, September 22, 1835). In the early 1900s, American journalists, travelers and politicians often depicted France as a decadent and effeminate nation (Verhoeven 2017). The same stereotypes were reinvigorated during the two world wars, when American soldiers complained about French fickleness and unreliability. ${ }^{10}$ As Franck Costigliola has shown, American officials in the Cold War era tended to view France "as a precariously perched domino, its people peculiarly susceptible to instability, license, and excess, all corollaries of what seemed a French perversion of the notion of liberty" (Costigliola 1992: 4-5). In sum, a wide array of anti-French stereotypes were readily available to all those who sought to attack France in 2003.

Another explanation as to why France was singled out by diplomats and the American media lies in the fact that, unlike the rest of Europe, the French lack a strong national constituency in the United States. Consequently, as Irwin Wall notes, "What is clearly politically incorrect and unacceptable when said of other national groups is permissible with regard to the French" (Wall 2004: 128). Indeed, it would be unthinkable, in $21^{\text {st }}$ century America, to publicly depict Germans, Russians or Italians as smelly, effeminate 
cowards whose faces deserved to be "rubbed in the merde" (Peters 2003). Yet the absence of a visible "French-American" political lobby in the United States allowed American editorialists to forego political correctness when it came to the French. ${ }^{11}$

After 2003, as after the Quasi-War, more cordial diplomatic relations resumed relatively quickly between France and the United States. With the 1800 treaty of Mortefontaine, the two nations annulled the treaty of Amity of 1778 but extended "most-favored" trading status to each other. In 1803, Napoleon sold the Louisiana territory to the United States for fifteen million dollars, opening a vast territory to American expansion. The two nations enjoyed amicable relations between 1840 and 1917, a time during which, as Jean-Baptiste Duroselle notes (1979: 485), "there were no common frontiers, no important political problems" between the two countries.

After the 2003 Iraq crisis also, normal relations between the two nations resumed in timely fashion. The process or rapprochement was gradual, as Frederic Bozo observes (2016: 297-300). It entailed increased cooperation between U.S. and French intelligence agencies in the fight against terrorism, France's reaffirmed commitment to NATO in Afghanistan, as well as renewed expressions of friendship during the celebration of the $60^{\text {th }}$ anniversary of the Normandy invasion. Both sides now avoided any kind of aggressive or hurtful rhetoric, and by 2005, full reconciliation was achieved. In February 2019, 81\% of Americans held a favorable view of France (Gallup Country ratings 2019), and talks of "Freedom fries" seemed like a distant memory. Yet the 2012 presidential campaign showed that anti-French rhetoric still could be used as a political weapon when Republican party nomination candidate New Gingrich sponsored a video clip titled "The French connection" against his opponent Mitt Romney. The short film, accompanied by a French accordion soundtrack, depicted Romney as a Frenchspeaking, elitist liberal (Mardell 2012). More recently, articles and editorials in The New York Times, The Washington Post, and other American media have continued to depict France and the French as resistant to progress, anti-Semitic, and contemptuous of their immigrant populations, often with few nuances. The various forms of Francophobia that have been described by Rosenthal (1999), Vaïsse (2003a), Mathy (2003) and others sometimes underlie the opinions of those who write of France and the French for the American public. As Shoat and Stam observe, "U.S. Francophobia, in sum, is the specular double of Americanophobia in France and displays the same earmarks of ethnoessentialist thinking" (Shohat \& Stam 2007: 131). Whether future diplomatic crises revive these mutual tendencies to blame a stereotyped "other" from across the Atlantic remains to be seen.

\section{BIBLIOGRAPHY}

Adams, Abigail. “Abigail Adams to Mary Smith Cranch, 26 April 1798.” Founders Online, https:// founders.archives.gov/documents/Adams/04-12-02-0273

“Anti-French incidents sporadic, but rising.” The Associated Press, March 23, 2003. 
Bowman, Albert Hall. The Struggle for Neutrality: Franco-American Diplomacy During the Federalist Era. Knoxville: U. of Tennessee P., 1974.

Bozo, Frédéric and Guillaume Parmentier. "La France et les États-Unis entre échéances intérieures et tensions internationales: une réconcilation limitée?" AFRI 8 (2007): 543-567. http:// www.afri-ct.org/article/la-france-et-les-etats-unis-entre

Bozo, Frédéric. A History of the Iraq Crisis. Trans. Susan Emanuel. New York: Woodrow Wilson Center Press, Columbia University, 2016.

Cleves, Rachel Hope. “'Jacobins in this Country': The United States, Great Britain, and TransAtlantic Anti-Jacobinism." Early American Studies 8.2 (Spring 2010): 410-445.

Cosgrove-Mather, Bootie. "Poll: talk first, fight later.” CBS news, January 23, 2003. https:// www.cbsnews.com/news/poll-talk-first-fight-later

Costigliola, Frank. France and the United States: The Cold Alliance Since World War II. New York: Twayne Publishers, 1992.

DeConde, Alexander. The Politics and Diplomacy of the Undeclared War with France, 1797-1801. New York: Charles Scribner's Sons, 1966.

De Gaulle, Charles. Entretien avec Michel Droit. December 14, 1965. https://fresques.ina.fr/degaulle/fiche-media/Gaulle00111/entretien-avec-michel-droit-deuxieme-partie.html

Den Hartog, Jonathan J. Patriotism and Piety: Federalist Politics and Religious Struggle in the New American Nation. Charlottesville: U. of Virginia P., 2015.

Duroselle, Jean-Baptiste. France and the United States. From the Beginnings to the Present Day. Chicago: U. of Chicago P., 1978.

Duroselle Jean-Baptiste and Bernard E. Doering. "Relations between Two Peoples: The Singular Example of the United States and France." The Review of Politics 41.4 (Oct.1979): 483-500. DOI: $10.1017 /$ S0034670500029156

Dwight, Timothy. The Duty of Americans, at the Present Crisis, Illustrated in a Discourse, Preached on the Fourth of July, 1798. New Haven: Thomas and Samuel Green, 1798.

Frank, Jerome D. and Melville, Adrei Y. "The Image of the Enemy and the process of change." In Anatoly Gromyko and Hellman Martin (eds). Breakthrough: Emerging New Thinking. Soviet and Western Scholars Issue a Challenge to Build a World Beyond War. New York: Walker and Company, 1988: 199-208.

Friedman, Thomas. “Our War with France.” The New York Times, September 18, 2003. https:// www.nytimes.com/2003/09/18/opinion/our-war-with-france.html

Gallup Country ratings 2019. https://news.gallup.com/poll/1624/perceptions-foreigncountries.aspx

Gertz, Bill. Treachery: How America's Friends and Foes Are Secretly Arming Our Enemies. New York: Crown Forum, 2004.

Gould, Eliga. Among the Powers of the Earth. The American Revolution and the Making of a New World Empire. Cambridge, Mass.: Harvard UP, 2012.

Hayes, Danny, and Matt Guardino. "Whose Views Made the News? Media Coverage and the March to War in Iraq." Political Communication 27.1 (2010): 59-87. DOI: 10.1080/10584600903502615

Hamilton, Alexander. “The stand III.” The [New York] Commercial Advertiser, April 7, 1798. 
Hoffman, Stanley. "Review of Our Oldest Enemy: A History of America's Disastrous Relationship With France.” Foreign Affairs 83.6 (Nov.-Dec. 2004): 153. https://www.foreignaffairs.com/reviews/ capsule-review/2004-11-01/our-oldest-enemy-history-americas-disastrous-relationship-france Ireland, Doug. "Baiting the French." The Nation. June 23, 2003. https://www.thenation.com/ article/archive/baiting-french/

Knowlton, Brian. "U.S. Officials Consider Ways to Punish France." International Herald Tribune. April 23, 2003a. https://www.nytimes.com/2003/04/23/international/worldspecial/us-officialsconsider-ways-to-punish-france.html

Knowlton, Brian. "France Says It Was Victim of Lies Fed by White House." The New York Times. May 15, 2003b. https://www.nytimes.com/2003/05/16/world/aftereffects-diplomacy-francesays-it-was-victim-of-lies-fed-by-white-house.html

Krauthammer, Charles. “The French Challenge.” The Washington Post. February 21, 2003. https:// www.washingtonpost.com/archive/opinions/2003/02/21/the-french-challenge/448f9feed4d5-48b0-a620-9deef96e1233

Kupchan, Charles A. How Enemies become Friends: the Sources of Stable Peace. Princeton: Princeton UP, 2010.

Lewis, Paul. "Meanwhile: Laughing all the way to the war - Opinion." International Herald Tribune, December 8, 2006. https://www.nytimes.com/2006/12/08/opinion/08iht-edlewis.3832831.html

Loughlin, Sean. "House cafeterias change names for 'French' fries and 'French' toast." CNN International, Wednesday, March 12, 2003. http://edition.cnn.com/2003/ALLPOLITICS/03/11/ sprj.irq.fries/

Macron, Emmanuel. "Transcription du discours lors de la cérémonie d'accueil à la Maison Blanche du Président de la République, Emmanuel Macron." 24 April 2018. https:// www.elysee.fr/emmanuel-macron/2018/04/24/ceremonie-daccueil-a-la-maison-blanche

Mathy, Jean Philippe. “The System of Francophobia.” French Politics, Culture \& Society 21.2 (Summer 2003): 24-32.

Mardell, Mark. "Mitt Romney lambasted in attack ad for speaking French." BBC news, 13 January 2012. https://www.bbc.com/news/world-us-canada-16549624

Milbank, Dana. “GOP Expose: Kerry, Closet Frenchman.” The Washington Post. March 23, 2004. https://www.washingtonpost.com/archive/politics/2004/03/23/gop-expose-kerry-closetfrenchman/0144e557-2c14-45de-8fd3-efb47a72b9f7

Mitchel, Daniel. "Punish France by Enlarging American Freedom." Capitalism Magazine. April 30, 2003. https://www.capitalismmagazine.com/2003/04/punish-france-by-enlarging-americanfreedom/

Mitchell, Daniel. "Better way to chastise France.” The Tribune-Democrat. April 21, 2003.

Mitterrand, François. “Allocution de M. François Mitterrand, Président de la République, lors de la cérémonie d'accueil à la Maison blanche.”. Washington, March 22, 1984. http://discours.viepublique.fr/notices/887020900.html

Molesky, Mark, and John J. Miller. Our Oldest Enemy: A History of America's Disastrous Relationship with France. New York: Doubleday, 2004.

Montgomery, David. "A Lot of Gaul; What's Behind the Latest Bashing? Some Vintage America Whine.” The Washington Post. March 1, 2003. 
Papenfuse, Robert Eric. The Evils of Necessity: Robert Goodloe Harper and the Moral Dilemma of Slavery. Philadephia: Transactions of the American Philosophical Society 87 pt. 1, 1997.

Peters, Ralph. "No Neutral Ground: a Message to France." The New York Post. September 24, 2003. https://nypost.com/2003/09/24/no-neutral-ground-a-message-to-france

Riché, Pascal. "Plus vieille alliée: la France est certes celle des Etats-Unis, mais..." L'Obs. September 4, 2013. https://www.nouvelobs.com/rue89/rue89-les-mots-demons/ 20130904.RUE8427/plus-vieille-alliee-la-france-est-certes-celle-des-etats-unis-mais.html Rosenthal, Alans S. "The Gender-Coded Stereotype: An American Perception of France and the French.” The French Review 72.5 (April 1999): 897-908.

Rubin, Barry, and Judith Colp Rubin. Hating America: A History. Oxford: Oxford UP, 2004.

Rumsfeld, Donald. "Rumsfeld: France, Germany are 'problems' in Iraqi conflict.” CNN.com world Thursday. January 23, 2003. http://edition.cnn.com/2003/WORLD/meast/01/22/sprj.irq.wrap Saad, Lydia. “Americans Still Reluctant to Call France an 'Ally'. U.S. image of France continues to be tainted by Iraq war disagreement”. Gallup News. September 26, 2003. https://news.gallup.com/ poll/9340/americans-still-reluctant-call-france-ally.aspx

Saad, Lydia. "France's Favorable Rating in U.S. Zooms to 87\%, a New High." Gallup News. February 25, 2016. https://news.gallup.com/poll/189602/france-favorable-rating-zooms-new-high.aspx

Shohat, Ella and Robert Stam. Flagging Patriotism: Crises of Narcissism and Anti-Americanism. New York and London: Routledge, 2007.

Smith, David Linvingstone. Less Than Human: Why We Demean, Enslave, and Exterminate Others. New York: St. Martin's Press, 2001.

Sonal S. Pandya and Venkatesan Rajkumar. "French Roast: Consumer Response to International Conflict-Evidence from Supermarket Scanner Data." Review of Economics and Statistics 98.1 (March 2016): 42-56. DOI: 10.1162/REST_a_00526

Stanley, Alexandra. "Threat and Responses: the TV Watch: After a Lengthy Buildup, An Anticlimactic Strike.” The New York Times: March 20, 2003. https://www.nytimes.com/ 2003/03/20/us/threats-responses-tv-watch-after-lengthy-buildup-anticlimactic-strike.html Trautsch, Jasper M. The Genesis of America. US Foreign Policy and the Formation of National Identity, 1793-1815. Cambridge: Cambridge UP, 2018.

Unger, Harlow Giles. The French War Against America: How a Trusted Ally Betrayed Washington and the Founding Fathers. Hoboken: John Wiley and Sons, 2005.

Vaïsse, Justin. “Le regain francophobe.” Politique Internationale 97 (Fall 2002): 1-7. http:// politiqueinternationale.com/revue/print_article.php?id=228\&id_revue=12\&content=texte Vaïsse, Justin. “American Francophobia Takes a New Turn.” French Politics, Culture \& Society 21.2 (Summer 2003a): 33-49. https://www.jstor.org/stable/42843285

Vaïsse, Justin. “Anonymous Sources: The Media Campaign Against France.” Brookings. Tuesday, July 1, 2003b. https://www.brookings.edu/articles/anonymous-sources-the-media-campaignagainst-france

Verhoeven, Timothy. "A French dandy in New York: Robert de Montesquiou and American visions of France in the Progressive era." Journal of Transatlantic Studies 15.4 (2017): 386-402. DOI: 10.1080/14794012.2017.1371458 
Vuorinen, Marja. “Enemy Images as Inversions of the Self. “ In Marja Vuorinen (ed.). Enemy Images in War Propaganda. Newcastle upon Tyne: Cambridge Scholars Publishing, 2012. 1-13.

Wall, Irwin M. “The French-American War Over Iraq”. The Brown Journal of World Affairs 10.2 (Winter/Spring 2004): 123-139. http://www.mafhoum.com/press6/176P3.pdf

Wilgoren, Jodi. “For Kerry, Taking Care Not to Get Lost in Translation.” New York Times. June 7, 2004. https://www.nytimes.com/2004/06/07/politics/trail/for-kerry-taking-care-not-to-getlost-in-translation.html

Will, George F. "Disregarding the deniers". The Washington Post. February 6, 2003. https:// www.washingtonpost.com/archive/opinions/2003/02/06/disregarding-the-deniers/ 4449fc5d-117e-421d-bc68-ad2b32f101f8

Williams, Greg H. The French Assault on American Shipping, 1793-1813: A History and Comprehensive Record of Merchant Marine Losses. Jefferson, North Carolina, and London: McFarland, 2009.

Willocks, W. “To the People of the United States: to battle!” Boston Gazette, August 27, 1798.

Willsher, Kim. "French students 'not welcome' in US." The Telegraph. June 8, 2003. https:// www.telegraph.co.uk/news/worldnews/northamerica/usa/1432359/French-students-notwelcome-in-US.html

Young, Gary and Jon Henley. "Wimps, weasels and monkeys - the US media view of "perfidious France." The Guardian, February 11, 2003. https://www.theguardian.com/world/2003/feb/11/ pressandpublishing.usa

\section{NOTES}

1. The list of reported losses is given in Williams 2009: 43-370.

2. As Frederic Bozo has shown, this rather large group included neo-conservative civilian officials in the Pentagon and in Dick Cheney's entourage, conservative Washington think tanks, as well as more moderate administration officials (Bozo 2016: 275). For a detailed study of this complex diplomatic crisis, see also Wall 2004.

3. On divisions among the American public concerning France, see the numbers given below in part III.

4. The Washington Times, which is owned by Sun Myung Moon's Unification Movement, is wellknown for its conservative outlook and fake news. The New York Post is owned by Rupert Murdoch, whose media empire (which includes Fox) often resorts to anti-French and antiEuropean rhetoric.

5. As Rachel Hope Cleves has shown, British and American attacks on French militarism in the late 1790 s frequently contained cannibalistic imagery that signified to readers the anarchic quality of Jacobin violence (Cleves 2010: 436).

6. Complaints by American G.I.s about French hygiene, morals and general unreliability are documented in the 1945 U.S. Military handbook 112 Gripes about the French, a text designed to defuse growing tensions between American soldiers and the French population.

7. See the ratings of the show at http://graphics.wsj.com/late-night-tv-show-ratings-and-hosts/.

8. The list also includes Barry Rubin and Judith Colp Rubin's Hating America: A History (2004), in which the history of modern France in summarized thus: "France, a society priding itself on its great history and even greater culture, trembled at any infusion of American culture because it assumed that there was no possibility of competing fairly [...] As a result, while France could easily have won any sneering contest, it lost the battles that truly counted" (149).

9. The details of the media campaign against France are presented in Vaïsse 2003b. 
10. These complaints are documented in the 1945 U.S. Military handbook 112 Gripes about the French.

11. On this idea see Vaïsse 2002. Jean-David Lévitte, the French Ambassador in Washington D.C. during the Iraq crisis, offered a partial solution to the problem of lack of French representation by reaching out to American Representatives and Senators. His efforts resulted in the creation of the Congressional French Caucus in February 2004.

\section{ABSTRACTS}

This article assesses the creation of an enemy image of France and the French in the United States in two separate historical contexts. Although France and the United States have usually enjoyed rather positive relations throughout history after the signing of the Treaty of Amity and Commerce in 1778, the French were widely depicted as America's enemy during the late 1790s Quasi-War, and more recently after France refused to support U.S. military intervention in Iraq in 2003-2004. In the first instance, an undeclared naval war opposed the two countries as the French government allowed for seizure of American ships in the wake of the 1795 Jay Treaty the US had signed with Great Britain, a conflict which escalated when U.S. navy later began to fight the French in the Caribbean. In 2003-2004, an acute diplomatic crisis induced a confrontation between the two nations when France suggested it would use its veto power to block passage of a United Nations Security Council resolution authorizing a U.S.- led military operation against Iraq. The aim of this study is to provide an understanding of the process through which the image of France was transformed, in both historical contexts, from that of ally and friend into that of a threatening other. Particular attention is paid to the creation and use of cultural stereotypes in statements by American officials, as well as in the media campaigns that characterized both diplomatic crises. Although the enemy image of France underwent significant changes between 1797 and 2003, our research shows that a number of cultural stereotypes that were created during the Quasi-War were revived during the 2003 diplomatic crisis. Chief amongst those is the association of France with terror and tyranny. This article also examines the deep political divisions that pitted Federalists against Republicans in the 1790s, and Neo-Conservative "hawks" against anti-war "doves" in 2003. These disputes shed light on the creation of enemy images of France in the United States. In both cases, the French antagonist was as mirror and a scapegoat that provides as much information on American identity and U.S. political debates as it does about American views on France and the French.

Cet article a pour objet d'apporter un éclairage sur la création de l'image d'un «ennemi français » dans deux contextes historiques distincts. Si les relations entre la France et les ÉtatsUnis ont généralement été cordiales depuis la signature du Traité d'Amitié et de Commerce de 1778, les Américains ont souvent décrit les Français comme leurs ennemis pendant la QuasiGuerre des années 1790, et plus récemment, lors de la crise diplomatique déclenchée en 2003 par l'intervention des États-Unis en Irak. Dans le premier cas, une guerre navale non déclarée a opposé les deux nations après la signature du Traité de Londres entre Anglais et Américains en 1795: suite à cet accord, le Directorat avait autorisé l'arraisonnement de navire marchands américains, provoquant un conflit qui s'étendit rapidement aux Antilles. En 2003-2004, une grave crise diplomatique a provoqué une confrontation entre les deux nations au moment où la France a menacé d'utiliser son droit de véto au Conseil de sécurité de l'ONU contre une résolution 
américaine qui aurait autorisé une opération militaire en Irak. Nous avons voulu comprendre le processus par lequel l'image de la France est passée de celle de pays allié des États-Unis à celle de nation hostile et menaçante. Dans cette optique, nous analysons l'usage de stéréotypes culturels dans les discours officiels de responsables américains, ainsi que dans les campagnes médiatiques qui ont marqué les deux crises. Bien que l'image d'un « ennemi français » ait subi d'importantes métamorphoses entre 1797 et 2003, nous constatons que plusieurs stéréotypes créés au moment de la Quasi-Guerre ont été réactivés lors de la crise diplomatique de 2003. L'image d'une France amie de la terreur et de la tyrannie ressort tout particulièrement des discours et des représentations étudiées. Les profondes rivalités politiques entre Fédéralistes et Républicains pendant la Quasi-Guerre, puis entre «faucons » néo-conservateurs et « colombes » opposées à la guerre en 2003, ont également retenu notre attention. Ces querelles éclairent la création d'images d'une "France ennemie »: dans les deux cas, l'antagoniste français a joué un double rôle de miroir et de victime sacrificielle. Ces deux fonctions sont tout aussi révélatrices de l'identité et de la politique américaines que de la manière dont les Américains perçoivent la France et les Français.

\section{INDEX}

Mots-clés: relations États-Unis-France, relations internationales, stéréotypes, Quasi-Guerre (années 1790), guerre d'Irak (2003), France

Keywords: USA-France relations, international relations, stereotypes, Quasi-War (1790s), Iraq war (2003), France

\section{AUTHOR}

\section{HERVÉ-THOMAS CAMPANGNE}

Professor of literature and cultural history at the University of Maryland, College Park. HervéThomas Campangne has published extensively on early modern French history and literature and is the author of articles on the history of France-USA relations. Contact: hcampang[at]umd.edu 